\title{
ТЛУМАЧЕННЯ РОЗСУДУ В КРИМІНАЛЬНОМУ ПРОЦЕСІ КРІЗЬ ПРИЗМУ ПРАВОВОЇ ДОКТРИНИ
}

Topбас 0. 0 .

\begin{abstract}
У науковій статmі досліджено основні підходи до тлумачення розсуду в праві. Для аналізу таких визначень було запропоновано відмовитися від єдиної класифікації визначень, замінивши ії групуванням відповідно до ознак, на які посилаються вчені у своїх визначеннях. Запропоноване авторське визначення розсуду в кримінальному процесі, де окремо акцентувалась увага на завданні розсуду й обставинах, які мають на нього впливати.
\end{abstract}

Ключові слова: дискреція, розсуд, розсуд у кримінальному процесі.

В научной статье исследованы основные подходи к толкованию усмотрения в праве. При анализе таких определений было предложено отказаться от единой классификации определений, заменив ее группированием в соответствии с признаками, на которые ссылаются ученые в своих оnределения. В качестве вывода было предложено авторское определение усмотрения в уголовном процессе, где акцентировалось внимание на задачах усмотрения и обстоятельствах, которые на него должны влиять.

Ключевые слова: дискреция, усмотрение, усмотрение в уголовном процессе.

In the scientific article basic approaches to the interpretation of discretion in law were investigated. Author stated that often discretion as a term was analyzed in law doctrine inextricably with the subject of discretion enforcement. Yet such condition in general had no influence of the outcome of such research, since fundamental understanding of discretion is the same no matter who must enforce such discretion.

For the purpose of analyzing such definitions it was suggested to abandon the single classification of definitions, replacing it with a grouping method according to the traits that scientists refer to in their definitions of law discretion, such as: amount of freedom (absolute, not absolute), purpose of application (the need to make a legitimate, most optimal decision; overcoming the uncertainty of legal acts), factors that should influence discretion (principles of law; internal belief; integrity and morality; the will of the legislator; professional experience); intellectual component. Thus author proved that many scientific opinion on the subject had something in common, which would be impossible to rove using standard classification.

As a conclusion, authors definition of discretion in criminal proceedings was suggested, according to which it should be considered as a power, which consists in the adoption by the intellectually mechanism obligatory to execute legally significant decision from several alternative according to the criminal procedural legislation taking into account circumstances of particular criminal proceeding, principles of criminal proceedings, professional experience of the law enforcer, judicial and investigative practice, moral and ethical characteristics of the subject of law, to ensure implementation of best private and public interests in criminal proceedings.

Key words: discretion, discretion in criminal proceedings.

Постановка проблеми та їі актуальність. Необхідно констатувати, що чинний Кримінальний процесуальний кодекс України (далі - КПК) містить достатньо велику кількість оцінних понять. Оцінними в кримінально-правовій доктрині вважаються такі поняття, зміст яких визначається не законом чи іншим нормативно-правовим актом, а правосвідомістю особи, яка застосовує відповідну правову норму, виходячи з конкретних обставин справи. Використовуючи їх, законодавець намагається надати суб'єкту застосування відповідної норми можливість максимально врахувати фактичні обставини справи, а також вимоги мінливих умов життя суспільства [1, с. 97]. Водночас застосування оцінних понять притаманне не лише кримінальному процесу, а й іншим галузям права. У зв'язку з цим науковці й практики все частіше почали звертатися до оцінки такого явища, як розсуд.

Аналіз останніх досліджень і публікацій. Проблематикою розсуду в праві переймалися такі вітчизняні й іноземні вчені, як Д.Б. Абушенко, Ю.С. Адушкін, В.Г. Антропов, М.В. Багрій, О.Я. Баєв, А. Барак, Л.Н. Берг, Л.М. Бєлкін, А.І. Бондюк, Н.В. Власенко, Ю.В. Гречева, П.В. Гук, В.Н. Дубовицький, К.П. Єрмакова, Я.П. Зейкан, В.С. Канцір, В.С. Ковальський, К.І. Комісаров, А.П. Корнєєв, М.Ф. Лук'яненко та багато інших.

Метою статті $\epsilon$ визначення сутності розсуду в кримінальному процесі шляхом аналізу тлумачень розсуду в правовій доктрині.

Виклад основного матеріалу. Тлумачні словники дають такі пояснення слова «розсуд»: розмірковування, роздум [2], рішення, висновок, думка [3, с. 839]. Такого тлумачення вже достатньо, щоб зрозуміти сутність цього поняття, адже розсуд у праві (в тому числі й у кримінальному процесі) змушує певних суб'єктів розмірковувати щодо способу й порядку застосування певного правового положення. Проте очевидним також $\epsilon$ те, що розсуд у праві має багато особливостей, які неможливо встановити, дослідивши лише лінгвістичне тлумачення. 3 цього приводу А. Барак слушно зазначає, що «в мові й науці термін «розсуд» має більше ніж одне значення і звичайно означає різні речі в різних контекстах» $[4$, с. $12-13]$.

О.Я. Баєв указував, що «в теорії права немає більш неформалізованого, а тому далеко неоднозначного поняття, ніж угляд (discrecio) у правозастосовній діяльності» [5, с. 438]. К.П. Єрмакова, проаналізувавши декілька тлумачень поняття «розсуд», зробила висновок, що воно містить два взаємопов'язані аспекти: 1) розумовий процес, результатом якого виступає певний вибір (розсуд - роздум - думка); 2) фактичний результат цього процесу, тобто конкретний вибір (розсуд - рішення). Відповідно до цього вчена зробила висновок, що розсуд являє собою вид розумової діяльності, який допомагає суб'єкту висловити своє ставлення до певної ситуації й дійти певного результату [6, с. 15].

Торбас 0. 0., 2019 
В.Н. Дубовицький указував на існування широкого й вузького тлумачення поняття «розсуд». У широкому розумінні розсуд - це рішення, думка, позиція. Автор вважає, що в такому розумінні право «зв'язано» розсудом. Відповідно у вузькому розумінні розсуд «зв'язаний» правом [7, с. 49]. Беззаперечною $\epsilon$ позиція Ю.А. Тихомирова про те, що проблема розсуду в рамках права повинна розглядатися як найважливіша для теорії права й усіх галузей правового регулювання [8, с. 158].

Досліджуючи визначення сутності поняття «розсуд" у наукових працях, насамперед необхідно зробити невелике уточнення. На доктринальному рівні досить часто досліджувався не сам розсуд, а розсуд конкретних суб'єктів, найчастіше - судовий розсуд. Дійсно, існують певні особливості розсуду в залежності від того, хто його застосовує. Крім того, існують особливості розсуду й залежно від галузі права, в якій відповідне поняття аналізується. Проте за своєю суттю такі наукові праці подібні між собою, адже сам зміст поняття «розсуд» $\epsilon$ незмінним незалежно від суб'єкта, який його застосовує, або галузі права, в якій його застосовують.

Повертаючись до питання визначення сутності поняття «розсуд», необхідно зауважити, що на доктринальному рівні це питання досліджувалось у достатній кількості наукових робіт. Проте єдиного підходу до визначення серед науковців так і не було вироблено. Для базового тлумачення можна використати позицію А. Барака, який досить лаконічно визначив розсуд як повноваження, яке дається особі під час вибору між двома або більше альтернативами, кожна з яких $є$ законною [4, с. 12]. Іншими словами «розсуд означає свободу вибору між різними можливими рішеннями» [4, с. 12].

Аналізуючи роботи науковців з цього питання, можна помітити певні спільні риси у тлумаченні відповідного поняття. Такі спільні характеристики зустрічаються незалежно від того, в якому обсязі досліджується проблематика розсуду й чи здійснюється науковцем прив'язка до конкретної галузі права або суб'єкта, на якого покладається обов'язок такий розсуд застосовувати. Проте такий висновок не можна плутати з позицією, відповідно до якої в правовій доктрині склалося єдине визначення розсуду в праві. Дійсно, розуміння розсуду, особливо з огляду на простоту лінгвістичного тлумачення цього поняття, $\epsilon$ спільним для більшості науковців і практиків, однак підхід до такого розуміння й виділення характерних ознак повною мірою демонструє багатогранність доктринальних напрацювань з цього питання.

Відмінності вказаних підходів обумовило те, що відносно недавно в правовій доктрині переважала позиція, відповідно до якої розсуд уповноважених суб'єктів був показником низької якості нормативно-правових актів, а тому сам розсуд розглядався як явище негативне. На думку В.М. Манохіна, командно-адміністративна система стала по суті хазяїном в суспільстві, водночас набувши таких хвороб, як бюрократизм, громіздкість, закостенілість організаційних форм [9, с. 27]. На сьогодні деякі науковці продовжують висловлювати негативне ставлення до розсуду $[10$, с. $11 ; 11]$, що, на думку А.С. Скурданова, пояснюється приматом позитивізму в праві пострадянських країн, відповідно до якого право розглядається як суворе, формальне, обов'язково-примусове явище, що обмежує свободу [12, с. 28].

Дійсно, якщо розглядати право з позиції «чистого» позитивізму, то розсуд має характеризуватися як сва- вілля уповноважених на правозастосування суб'єктів, яке неможливо контролювати й наслідки якого неможливо передбачити. Така правова невизначеність може тягнути за собою правовий нігілізм, адже учасники правовідносин більше не бачитимуть можливості захистити свої права й законні інтереси через застосування й підкорення правовим нормам. Крім того, розсуд також завжди може розглядатися як досить серйозний корупційний ризик $[13 ; 14 ; 15]$. Проте така ситуація може стати реальністю тільки в одному випадку, якщо право розглядати виключно з позиції позитивізму, а це неможливо. Нормативно-правові акти або в силу своєї недосконалості (фактор, який буде присутній у будьякій правовій системі в усі часи), або в силу бюрократичної тяганини, пов'язаної з їх оновленням, або в силу наддинамічного розвитку суспільства ніколи не зможуть повною мірою описати всі правовідносини, які виникають або зможуть виникнути, а тим більше закріпити всі процедури, яким мають слідувати правозастосовувачі в будь-яких ситуаціях.

У зв'язку з цим варто констатувати, що розсуд залишається достатньо важливим способом регулювання правовідносин у будь-якій галузі права незалежно від правової системи. А всю критику треба звертати не в бік розсуду як окремого явища, а в бік складності його застосування, що стає причиною суттєвого зниження рівня правозастосування.

А.М. Ніконов, аналізуючи у своїй науковій роботі основні положення правової доктрини щодо розсуду, розподілив усі підходи до розуміння розсуду на три блоки: 1) формально-юридичний, який розглядає розсуд як «повноваження»; 2) філософський розуміє розсуд як «вибір» чи «свободу»; 3) розумово-діяльний характеризує розсуд як «розумову діяльність» або «правозастосовчий акт (діяльність)» [16, с. 18]. В цьому випадку вчений, аналізуючи різні наукові підходи до тлумачення поняття «розсуд», взяв за основу ключове слово (словосполучення), яким характеризується це поняття, а саме: розсуд як повноваження, розсуд як свобода вибору тощо. Такий підхід видається досить слушним, адже будь-яке визначення можна замінити одним або декількома словами, на які автор відповідного тлумачення робить змістовий наголос.

Попри відносну простоту й логіку такого підходу групування тлумачень розсуду повністю вдалим його назвати складно, адже досить часто неможливо віднести конкретне визначення лише до одного блоку. Як уже було встановлено, розсуд полягає в наданні відповідним суб'єктам повноваження вільно вибирати одну з декількох альтернатив у процесі правозастосування. Таким чином, розсуду притаманні всі три характеристики, а тому поділ тлумачень на вказані блоки фактично унеможливлює об'єднання цих ознак одним тлумаченням, що суперечить більшій частині наукових напрацювань щодо цього питання.

Тому в цьому дослідженні пропонується дещо інша система порівняння тлумачень терміну «розсуд». 3 огляду на відносну подібність усіх визначень і неможливість виділення окремих категорій за будь-якою ознакою (адже запропоновані науковцями тлумачення можуть належати відразу до декількох груп), пропонується виділяти з усього переліку окремі тлумачення, які мають унікальні властивості відносно інших, у зв'язку з чим їх легше аналізувати. 
Відповідно першою властивістю в цьому випадку можна назвати обсяг свободи, яким характеризується розсуд. Розсуд надає можливість уповноваженому суб'єкту обирати один варіант із декількох альтернативних. Проте не всі науковці з цим погоджуються. Так, Д.М. Чечот стверджує, що поняття «розсуд» вказує на можливість відповідного органу чи посадової особи діяти по своїй волі, не зв'язаній у прийнятті рішення будь-якою нормою [17, с. 68]. А.В. Ярославський розуміє розсуд як ставлення слідчого (судження, оцінка) до характеру ситуації, що розглядається, обумовлене деякими його індивідуальними якостями й виражене у формі права вільного вибору рішення (дії) чи часу прийняття рішення (дії), що буде найбільш доцільним з погляду накопиченого кримінально-процесуальною практикою досвіду правозастосування для досягнення завдань кримінального судочинства в тій чи іншій конкретній слідчій ситуації [18, с. 6]. В.Л. Кулапов та Ю.В. Медная дійшли висновку, що судовий розсуд полягає у вільному визначенні позиції судді на основі творчого, системного сприйняття чинного права, правозастосовної практики й фактичних обставин справи $[19$, с. 168]. М.Ф. Лук'яненко визначає розсуд як спосіб творчої реалізації цивільноправових норм, що полягає у вільно-суб'єктивному виборі поведінки, яка заснована на внутрішньому переконанні правозастосувача, шляхом оцінювання конкретної ситуації [20, с. 1947]. В.В. Лазарев розсуд розглядає як вирішення справи, виходячи з основ, які закладені в самому суб'єкті застосування права. Він спирається на внутрішні джерела формування волі відносно кінцевого розв'язання питання [21, с. 144]. А.А. Малиновський зазначає, що розсуд - вибір суб'єктом певної цілі та способів ії досягнення або можливість висловлювати свою волю й приймати рішення незалежно від волі інших осіб [22, с. 102]. О.С. Скударнов вважає, що розсуд у процесі реалізації права - це закріплена в нормативно-правових засобах свобода вибору суб'єктів у реалізації конкретної юридичної справи (питання) в межах індивідуального правового регулювання з метою ефективної та сприятливої для особи організації й безпосередньої реалізації прав, свобод, виконання й дотримання обов'язків [23, с. 70]. О.В. Геселев стверджує, що розсуд - усвідомлена суб'єктом правових відносин можливість вибору найбільш оптимального, пріоритетного варіанту правомірної поведінки, що виходить з аналізу правового припису й конкретних життєвих обставин (у тому числі мети, інтересу, що має бути задоволеним, тощо) [24, с. 474]. На думку Я.П. Зейкана, судовий розсуд - це вибір суддею варіанта рішення юридичної справи, що ґрунтується на його суб'єктивному сприйнятті обставин справи та його суб'єктивному тлумаченні правових норм [25, с. 21].

Не можна стверджувати, що перераховані науковці повною мірою дотримуються позиції, що розсуд повністю залежить від волі суб'єкта, який його застосовує, i ніяк не обмежений нормативно-правовими актами. Проте інші вчені $\epsilon$ більш категоричними в цьому питанні, зокрема дають прямі вказівки на цю обставину у власних тлумаченнях поняття «розсуд». Існують навіть доволі радикальні позиції щодо обмеження свободи застосування розсуду суб'єктом такого застосування. Так, наприклад, А.Т. Боннер розглядає судовий розсуд як повноваження суду, що передбачене законом та може бути реалізовано виключно в рамках закону, розв'язувати правові питання, виходячи з обставин справи, загальних положень закону, принципів права, економічних законів і норм моралі. Водночас суд, реалізуючи таку діяльність, або не вільний у своїй поведінці, або має лише незначні ознаки свободи [26, с. 48].

Іншою властивістю, яка дає змогу встановити окрему групу 3-поміж усього масиву тлумачень розсуду, $\epsilon$ виділення мети застосування розсуду. У більшості випадків учені виділяють таку мету, як необхідність прийняття законного, найбільш оптимального рішення. Так, наприклад, Ю.П. Соловей стверджує, що адміністративний розсуд необхідно розуміти як оцінку фактичних обставин, підстави (критерії) якої не закріплені в правових нормах достатньо повно чи конкретно, яка здійснюється органом (посадовою особою) в разі обрання в межах, які допускаються нормативно-правовими актами, оптимального варіанта розв'язання конкретного управлінського питання [27, с. 14]. Л.Н. Берг вважає, що судовий розсуд - це елемент правозастосовчої діяльності, який полягає у виборі вмотивованого, законного й обґрунтованого рішення, що реалізується уповноваженим на те суб' єктом (суддею) щодо конкретної юридичної справи в межах, установлених нормою права [28, с. 61-62]. А.І. Бондюк вважає, що суддівський розсуд слідчого судді - це ментальна форма реалізації процесуальних повноважень, що обмежуються вказівкою припису процесуальної норми закону або умовою ii відсутності, результатом якої $\epsilon$ винесення правомірного, оптимально ефективного рішення, в основу якого покладено обґрунтовані підстави з урахуванням основних засад кримінального судочинства, мети досудового розслідування й положень про захист основоположних прав, свобод та інтересів людини [29, с. 425].

Окрема група авторів також наголошує на тому, що метою розсуду має бути подолання невизначеності нормативно-правових актів. У такому випадку розсуд розглядається як направлені на подолання фактичної й правової невизначеності й узгоджені з принципами кримінального судочинства повноваження суду застосовувати на основі власного внутрішнього переконання один з декількох легітимних варіантів розв'язання правових питань з метою найбільш ефективного здійснення кримінального судочинства (К.В. Пронін) [30, с. 7]; як зумовлене відносною невизначеністю права певним чином обмежене повноваження суду обирати такий варіант вирішення конкретної справи, який $€$ максимально доцільним і справедливим у відповідній ситуації (Г.П. Мельник) [31, с. 45]; як обраний слідчим (у випадку, коли це стосується слідчого) в межах своїх повноважень із декількох альтернатив (кожна з яких $\epsilon$ законною) варіант поведінки, який або прямо передбачений у правовій нормі, або виплаває з їі змісту, або виникає через недосконалість конкретності чи повноти нормативного закріплення, у формі кримінально-процесуального акту (рішення) в межах конкретного кримінально-процесуального провадження (М.В. Багрій) [32, 2].

Наступною властивістю, яка також може бути підставою для виділення окремих тлумачень розсуду, $\epsilon$ фактори, які мають впливати на розсуд уповноважених суб'єктів. Необхідно зауважити, що майже в усіх визначеннях трапляється такий фактор, як оцінка фактичних обставин конкретної справи (провадження), тому в цьому дослідженні окремо його виділяти немає сенсу. 
За такої обставини в окремі групи необхідно включити ті тлумачення, в яких автори посилаються на можливість застосування основних засад (принципів) права. Так, А.П. Корнєєв зазначає, що судовий розсуд - це надання суду повноважень приймати в залежності від конкретних умов таке рішення з питань права, можливість якого витікає із загальних і лише відносно визначених приписів закону і яке надається йому з метою прийняття оптимального рішення в справі [33, с. 70]. К.І. Комісаров під судовим розсудом розуміє специфічний вид судово-застосовної діяльності, сутність якого проявляється в наданні суду в певних випадках повноважень приймати відповідно до конкретних умов таке рішення з питань права, можливість якого витікає із загальних і лише відносно визначених законодавчих приписів [34, с. 50]. Також прикладом у цьому випадку можуть бути вже згадані визначення А.Т. Боннера, К.В. Проніної та інших.

Також обставинами можуть бути такі чинники:

внутрішнє переконання суб'єкта правозастосування (розсуд як встановлена правом можливість відповідного органу, посадової особи обирати під час вирішення дисциплінарної справи найбільш доцільний, на його думку, варіант поведінки, як визначений альтернативними нормами, так і взагалі ними не регламентований (Ю.С. Адушкін) [35, с. 260];

- добросовісність і мораль (судовий розсуд - це врегульований правовими нормами, здійснюваний в процесуальній формі специфічний вид правозастосовної діяльності, сутність якого проявляється в наданні суду в певних випадках повноважень вирішити спірне правове питання, виходячи з цілей, які ставив перед собою законодавець, принципів права й інших положень закону, конкретних обставин справи, а також розумності, добросовісності, справедливості й основ моралі (0.П. Папкова) [36, с. 107];

воля законодавця (судовий розсуд в кримінальному праві - здійснюваний у процесуальній формі специфічний аспект правозастосовної діяльності, який полягає у використанні наданих суду (слідчому, дізнавачу) кримінально-правовими нормами повноважень щодо вибору рішень у межах, установлених законом, згідно зі своєю правосвідомістю та волею законодавця, виходячи з принципів права і конкретних обставин вчиненого злочину (Ю.В. Грачова) [37, с. 144];

- професійний досвід (розсуд - надане судді законом і статутом право й обов'язок свободи вибору одного з декількох закріплених у правовій нормі рішень конкретної справи, що базується на його світогляді, професійному досвіді й переконанні (Н.С. Погорєлова) [38, с. 28] тощо.

Аналізуючи наукові підходи до визначення сутності поняття розсуду, можна помітити значну частину вчених, які окремо виділяють інтелектуальну (розумову) складову при застосуванні розсуду. Це такі вчені:

- П.А. Гук, який розглядає розсуд як розумово-аналітичну діяльність судді (суду) щодо вибору єдино вірної правової норми, правової позиції, правозастосування судової практики за наявності декількох легітимних варіантів для застосування відносно правовідношення, що не визнається, чи напрацювання спільного правоположення [39, с. 46];

В.Г. Антропов, для якого правозастосовний розсуд - це надана правом владна інтелектуально-вольова діяльність правозастосувача щодо вибору суб'єктивно-оптимального рішення [40, с. 62];

В.С. Ковальський, який розуміє судовий розсуд як інтелектуально-вольовий елемент судової діяльності, що полягає в розумінні (сприйнятті, зіставленні) суддями предмета розглядуваних справ і прийнятті рішень у відносно визначених межах дії кримінально-правових норм [41, с. 114];

- М.Д. Савенко, за яким суддівський розсуд - це інтелектуально-вольова діяльність, спрямована на законне, об'єктивне, неупереджене й справедливе вирішення спірних питань, що виникають у судочинстві або $є$ предметом розгляду у випадках, дозволених або не врегульованих законом [42, с. 75];

В.М. Канців, який зазначає, що суддівський розсуд - це дозволена кримінальним і кримінально-процесуальним законом інтелектуальна діяльність суду, змістом якої $\epsilon$ проведення оцінки кримінально-правових та інших явищ і здійснення вибору одного з декількох допустимих межами відносно визначеної за змістом кримінально-правової й кримінально-процесуальної норми варіанту правозастосовного рішення для забезпечення законності [43, с. 10$]$;

Н.А. Власенко, який указує, що судовий розсуд це владна діяльність суду щодо здійснення правосуддя з допомогою інтелектуально-вольового механізму, який дає змогу суду здійснити вибір варіантів вирішення юридичної справи, [44, с. 56] та інші.

До визначень, які через свою лаконічність не отримали місця в цих групах, можна віднести тлумачення розсуду слідчого П.В. Марфіцина, за яким розсуд - це обраний слідчим у межах своїх повноважень з-поміж альтернатив, кожна з яких $\epsilon$ законною, варіанта поведінки (рішення), який відповідає конкретним умовам справи [45, с. 103]; визначення Ю.А. Тихомирова, який вважає розсуд мотивованим вибором для прийняття правомірних рішень і реалізації дій уповноваженим суб'єктом у межах його компетенції для виконання поставлених завдань [46, с. 72]; розуміння судового розсуду Д.Б. Абушенка, в якого судовий розсуд базується на свободі суду, його праві вибору, відносному характері свободи, обмеженості свободи, а встановлення свободи й способи її обмеження витікають безпосередньо з правових норм [47, с. 24]; В.О. Бігуна, який розглядає розсуд, як межі свободи судді в судовому вирішенні, спосіб реалізації судової влади суддею, принципове положення в здійсненні правосуддя, що визначає межі повноважень суду у вирішенні питань і справ у судочинстві [48, с. 22], та інших.

Висновки. Враховуючи відносну сталість розуміння сутності розсуду в правовій доктрині, можна зробити висновок, що розсуд у кримінальному процесі - це повноваження, яке полягає в прийнятті за допомогою інтелектуально-вольового механізму одного обов'язкового для виконання юридично значущого законного рішення з декількох запропонованих кримінальним процесуальним законодавством альтернатив відповідно до обставин конкретного кримінального провадження 3 урахуванням засад кримінального провадження, професійного досвіду правозастосувача, судової й слідчої практики, моральних і етичних характеристик суб'єкта правозастосування задля найкращого забезпечення приватних і публічних інтересів у кримінальному провадженні. 


\section{Література}

1. Наумов А.В. Применение уголовно-правовых норм. По материалам следственной и прокурорско-судебной практики : учеб. пособ. Волгоград : Изд-во ВСШ МВД СССР, 1973. 176 с.

2. Академічний тлумачний словник української мови : веб-сайт. URL: http://sum.in.ua/s/rozsud (дата звернення 02.02.2020).

3. Ожегов С.И. Словарь русского языка. Москва : Советская энциклопедия, 1973. 944 с.

4. Барак А. Судейское усмотрение / пер. с англ. Москва : Норма, 1999. с. 364.

5. Баев О.Я. Усмотрение в уголовном судопроизводстве. Вестник ВГУ. Серия «Право». 2010. № 1. С. 438-450.

6. Ермакова К.П. Пределы судебного усмотрения: дисс. ... канд. юрид. наук : 12.00.01. Москва, 2010. 212 с.

7. Дубовицкий В.Н. Законность и усмотрение в советском государственном управлении. Минск : Наука и техника, 1984. $141 \mathrm{c.}$

8. Тихомиров Ю.А. Правовое регулирование: теория и практика. Москва : Формула права, 2010. 400 с.

9. Манохин В.М. Правовое государство и проблема управления по усмотрению. Советское государство и право. 1990. № 1. С. 23-30.

10. Шестакова Н.Д. Недействительность сделок: процессуальный и материальный аспекты : автореф. дис. ... канд. юрид. наук: 12.00.15. Санкт-Петербург, 2001. С. 21.

11. Шарнина Л.А. К вопросу о разграничении усмотрения и произвола в конституционном праве. Конституционное и муниципальное право. 2011. № 7. С. 11-14.

12. Скурданов А.С. К вопросу об усмотрении в праве. Сибирский юридический вестник. 2012. № 3 (58). С. 27-33.

13. Петрова А.С. Дискреційні повноваження судді у кримінальному судочинстві як один із видів корупційних ризиків судової системи України. Вісник кримінального судочинства. 2017. № 1. С. 156-163.

14. Бєлкін Л.М. Дискреційні повноваження органів влади як чинник корупції. Боротьба з організованою злочинністю і корупцією (теорія і практика). 2011. Вип. 24. С. 91-100.

15. Шатрава С.О. Дискреційні повноваження працівників ОВС як корупційний ризик у діяльності органів внутрішніх справ. Порівняльно-аналітичне право. 2013. № 2. С. 276-277.

16. Никонов М.А. Судейское усмотрение: уголовно-процессуальные аспекты : дис. ... канд. юрид. наук : 12.00.09. Москва, 2013. 272 с.

17. Чечот Д.М. Административная юстиция (теоретические проблемы) : монография. Ленинград : Издательство Ленинградского университета, 1973. 134 с.

18. Ярославский А.Б. Усмотрение следователя при расследовании уголовных дел : автореф. дис. ... канд. юрид. наук : 12.00.09. Волгоград, 2001. 21 с.

19. Кулапов В.Л., Медная Ю.В. Поднормативное правовое регулирование. Саратов: Изд-во ГОУ ВПО «Саратовская государственная академия права», 2009. 199 с.

20. Лукьяненко М.Ф. Усмотрение как способ применения оценочных понятий гражданского права. Право и политика. 2008. № 8. С. 1940-1947.

21. Лазарев В.В. Применение советского права / науч. ред. Б.С. Волков. Казань : Изд-во Казанского ун-та, 1972. 200 c.

22. Малиновский А.А. Усмотрение в праве. Государство и право. 2006. № 4. С. 102 Б.С.104.

23. Скударнов А.С. Усмотрение в процессе реализации прав, свобод и обязанностей граждан (и их объединений) : дисс. ... канд. юрид. наук : 12.00.01. Красноярск, 2014. 211 C.
24. Геселев О.В. Проблеми взаємодії праворозуміння та розсуду правозастосувача при обґрунтуванні процесуальних рішень у кримінальному судочинстві: філософсько-правовий аналіз. Держава і право. 2009. Вип. 46. С. 473-479.

25. Зейкан Я.П. О проблеме свободного судебного усмотрения в арбитражном процессе. Вестник Арбитражного суда Ставропольского края. 2004. № 1. С. 21.

26. Боннер А.Т. Применение нормативных актов в гражданском процессе. Москва: Юрид. лит., 1980. 142 C.

27. Соловей Ю.П. Усмотрение в административной деятельности советской милиции : автореф. дисс. ... канд. юрид, наук : 12.00.02. Москва, 1982. 22 с.

28. Берг Л.Н. Судебное усмотрение и его пределы (общетеоретический аспект) : дисс. ... канд. юрид. наук : 12.00.01. Екатеринбург, 2008. 196 с.

29. Бондюк А. Аналіз наукових підходів до визначення поняття “судовий розсуд". Вісник Начіонального університету «Львівська політехніка". Серія «Юридичні науки» : збірник наукових праць. 2017. № 861. C. $422-426$.

30. Пронин К.В. Дискреционные полномочия суда в уголовном судопроизводстве : автореф. дисс. ... канд. юрид. наук : 12.00.09. Челябинск, 2010. 25 с.

31. Мельник Г.П. Судовий розсуд (дискреція) як явище правової системи. Наукові записки Національного університету «Києво-Могилянська академія». 2009. Т. 90 : Юридичні науки. С. 44-47.

32. Багрій М.В. Угляд (розсуд) слідчого в кримінальному судочинстві України: до питання визначення поняття. Часопис Академії адвокатури України. 2011. № 13. С. 1-5.

33. Корнеев А.П. Административное усмотрение в применении законодательства об ответственности за правонарушения. Проблемы теории и практики административной ответственности в свете решений XXV съезда КПСС и Конституции СССР : материалы научно-практической конференции. Москва, 1979. С. 66-70.

34. Комиссаров К.И. Судебное усмотрение в советском гражданском процессе. Советское государство и право. 1969. № 4. С. 49-56.

35. Адушкин Ю.С. О принципах процессуальной экономии и административного усмотрения в дисциплинарном производстве. Правопорядок и правовой статус личности в развитом социалистическом обществе в свете Конституции СССР 1977 года. Саратов : Саратов. ун-т, 1980. C. 258-261.

36. Папкова О.А. Понятие судейского усмотрения. Журнал российского права. 1997. № 12. С. 98-118.

37. Гречева Ю.В. Судейское усмотрение в реализации уголовно-правовых норм: проблемы законотворчества, теории и практики : дисс. ... докт. юрид. наук : 12.00.09. Москва, 2011. 535 с.

38. Погорелова Н. С. Судейское усмотрение в производстве по делам об административных правонарушениях : дис. ... канд. юрид. наук : 12.00.14. Ростов-наДону, 2005. 173 с.

39. Гук П.А. Независимость и судейское усмотрение. Российская юстиция. 2008. № 11. С. 45-47.

40. Антропов В.Г. Правоприменительное усмотрение: понятие и формирование (логико-семантический аспект) : дисс. ... канд. юрид. наук : 12.00.01. Волгоград, 1995. 20 с.

41. Ковальський В.С. Проблема суддівського розсуду та кримінальний закон. Судова реформа в Україні: проблеми i перспективи : матеріали наук.-практ. конф., м. Харків, 18-19 квітня 2002 р. Київ : Юрінком Інтер, 2002. С. 112-114.

42. Савенко М.Д. Суддівський розсуд у цивільному процесі. Наукові записки. Юридичні науки. 2004. Т. 26. c. 75-79. 
43. Канцір В.С. Проблеми судового угляду при застосуванні кримінального законодавства України : автореф. ... дис. канд. юрид. наук : 12.00.08. Львів, 1998. 20 с.

44. Власенко Н.А. Проблемы точности выражения формы права (лингво-логический анализ) : автореф. дис. ... докт. юрид. наук : 12.00.01. Екатеринбург, 1997. 71 с.

45. Марфицин П.В. Усмотрение следователя (Уголовнопроцессуальный аспект): дисс. .. докт. юрид. наук : 12.00.09. Омск, 2003. 418 с.

46. Тихомиров Ю.А. Административное усмотрение и право. Журнал российского права. 2000. № 4. С. 70-79.
47. Абушенко Д.Б. Судебное усмотрение в гражданском процессе: дисс. ... канд. юрид. наук : 12.00.03. Москва, 2002. 164 с.

48. Бігун В.С. Філософія правосуддя: ідея та здійснення : монографія. Київ, 2011. 303 с.

Tорбас 0. O., кандидат юридичних наук, доцент кафедри кримінального процесу Національного університету «Одеська юридична академія» 